\title{
Insights into rapid composting of paddy straw augmented with efficient microorganism consortium
}

\author{
Anamika Sharma $\cdot$ Richa Sharma $\cdot$ \\ Anju Arora $\cdot$ Raghubir Shah · Arjun Singh • \\ Kumar Pranaw $\cdot$ Lata Nain
}

Received: 29 September 2013 / Accepted: 12 March 2014/Published online: 3 April 2014

(C) The Author(s) 2014. This article is published with open access at Springerlink.com

\begin{abstract}
Background The objective of this study was to develop a consortium of effective microorganisms to hasten the composting process and to reduce the composting period.

Results An efficient microorganism (EM) consortium was developed using Candida tropicalis (Y6), Phanerochaete chrysosporium (VV18), Streptomyces globisporous (C3), Lactobacillus sp. and enriched photosynthetic bacterial inoculum for rapid composting of paddy straw. Paddy straw was amended with poultry droppings to narrow down its $\mathrm{C}: \mathrm{N}$ ratio for faster degradation. Composting was carried out in open pits with EM consortium and compared with compost inoculant (CI) consisting of Aspergillus nidulans (ITCC 2011), Trichoderma viride (ITCC 2211), Phanerochaete chrysosporium (NCIM 1073) and A. awamori (F-18). Changes in biochemical and physiochemical parameters like $\mathrm{C}: \mathrm{N}$ ratio, $\mathrm{pH}, \mathrm{EC}$ and humus were studied over a period of 60 days to test compost maturity and stability along with microbial and extracellular hydrolytic enzyme activities. Paddy straw amended with EM and $\mathrm{CI}$ hasten the composting process by bringing $\mathrm{C}: \mathrm{N}$ ratio down to 15:1 and achieving a total humus content of $4.82 \%$ within 60 days. High activity of hydrolytic enzyme carboxymethyl cellulase (CMCase) ( $0.43 \mathrm{IU} / \mathrm{g}$ ) and microbial activity in terms of dehydrogenase $(158.64 \mu \mathrm{g} \mathrm{TPF} / \mathrm{g} / \mathrm{day})$ was observed in this treatment. The activity of xylanase was positively correlated $(r=0.987)$ with alkali-soluble carbon.
\end{abstract}

Electronic supplementary material The online version of this article (doi:10.1007/s40093-014-0054-2) contains supplementary material, which is available to authorized users.

A. Sharma $\cdot$ R. Sharma $\cdot$ A. Arora $\cdot$ R. Shah - A. Singh .

K. Pranaw $\cdot$ L. Nain $(\bowtie)$

Division of Microbiology, Indian Agricultural Research

Institute, New Delhi 110012, India

e-mail: latarajat@yahoo.co.in
Conclusion This study illustrates the importance of microbial bioaugmentation to hasten the composting process of paddy straw to produce quality compost.

Keywords Bioconversion - Crop residue $\cdot$ EM · Recycling · Degradation - Poultry droppings - Maturity · Stability

\section{Introduction}

After the green revolution, India is self-sufficient in the production of food, but to meet the future need of food grains for the burgeoning population, extensive cropping is being practised which affects the soil health. Intensive use of chemical fertilizers and pesticides further deteriorates soil fertility. To restore the productivity of soil, recycling of crop biomass and compost application in the field is a good alternative (Gaind and Nain 2007). India is the second largest producer of rice and more than 100 million tons of paddy straw is produced in India every year (Veena and Pandey 2011). Paddy straw contains high amount of silica $(>9.0 \%)$ and is therefore not suitable as animal feed. In northern India, surplus paddy straw residue is generally either left in the field or to a large extent burnt in open field. Burning of paddy straw and greenhouse gases (GHG) emissions cause severe air pollution. According to a research, GHG emissions contribution through open-field burning of rice straw in India, Thailand, and the Philippines are $0.05,0.18$, and $0.56 \%$ respectively (Gadde et al. 2009). Alternatively, use of paddy straw for composting is the best alternative to manage this resource, along with its use for restoration of soil health (Gaind et al. 2008).

Composting is a process in which conversion of heterogeneous organic matter occurs through decomposition and 
humification. In recent years, interest in composting has increased because of the social demand for an environmentally friendly waste treatment technology and advent of organic farming. It is the most acceptable methods of recycling of organic matter and agriculture residues (Antil and Raj 2012). Although small amount of GHG emission occurs during the process of composting, substrate with low $\mathrm{C}: \mathrm{N}$ ratio releases higher $\mathrm{NH}_{3}$ and $\mathrm{CH}_{4}$ emission (Jiang et al. 2011). Since composting is a microbial degradation process, C:N ratio is the most important factor to initiate the composting process. $\mathrm{C}: \mathrm{N}$ ratio must be around 50:1 at the initiation stage for the composting process to proceed at a faster pace. As the $\mathrm{C}: \mathrm{N}$ ratio $(90: 1)$ of paddy straw is very high, it is essential to bring down the $\mathrm{C}: \mathrm{N}$ ratio by supplying an exogenous nitrogen source. Poultry droppings is a good supplement due to its high nitrogen content, and therefore amendment of paddy straw with poultry dropping is a desirable option to bring down the C:N ratio of paddy straw (Devi et al. 2010).

In nature, the bioconversion rate of paddy straw is slow and natural microflora participates in degradation of the crop waste. Therefore, bioaugmentation of composting material (paddy straw and poultry dropping) with efficient microbes may improve and/or accelerate the composting process. The concept of efficient microorganism (EM) was first developed by the Japanese horticulturist Teruo Higa in 1970s at Okinawa. He reported that a combination of indigenous organisms can influence the decomposition process of organic matter. EM uses indigenous effective microorganisms; which are non-pathogenic and include lignocellulolytic fungi, cellulolytic bacteria, lactic acid bacteria, yeast, and photosynthetic bacteria. EM acts as activator and hastens the composting process by creating a suitable environment for degradation (Daly and Stewart 1999).

In our laboratory, a consortium of four lignocellulolytic fungi was developed earlier for faster degradation of crop residue, but the period of composting was at least 90 days. Since EM may also be useful for further improvement in the decomposition process, the present study was aimed to know the efficiency of EM culture alone as well as along with compost inoculant developed earlier (Pandey et al. 2009). We also monitored the biochemical process through estimation of microbial enzyme activity during composting of paddy straw. The physiochemical and biochemical parameters were also correlated with maturity parameters which determine the quality of the compost.

\section{Materials and methods}

\section{Substrate}

Fresh paddy straw (var. Pusa Basmati1) was collected from Indian Agricultural Research Institute (IARI) farms, and was amended with poultry droppings collected from poultry farms located in peri-urban areas of New Delhi. Composting was carried out in perforated compost pits measuring $1 \mathrm{~m}^{2}$ and located in the premises of Division of Microbiology, IARI, New Delhi.

\section{Development of inocula for augmentation of compost}

Two types of inoculants were used for bioaugmentation of paddy straw: compost inoculant (CI) and efficient microorganism (EM). The CI consortium consisted of four promising lignocellulolytic fungi, Aspergillus nidulans (ITCC 2011), Trichoderma viride (ITCC 2211), Phanerochaete chrysosporium (NCIM 1073), A. awamori (F-18) selected on the basis of their compatibility and lignocellulolytic enzyme production potential (Pandey et al. 2009). A. nidulans (ITCC 2011) and T. viride (ITCC 2211) were procured from the Indian Type Culture Collection (ITCC), IARI, New Delhi, India. P. chrysosporium (NCIM 1073) was procured from National Chemical Laboratory (NCL), Pune, India, and A. awamori (F-18) an isolate from soybean rhizosphere, was procured from Division of Microbiology, IARI, New Delhi. All the fungal cultures were maintained on potato dextrose agar slant.

For the development of EM consortium, several native isolates of yeast, actinomycetes, and fungi were screened for their hydrolytic enzyme production potential. Best cultures with high enzyme production potential as well as compatibility testing were selected for the EM consortium, which consisted of Candida tropicalis (Y6) isolated from rotten fruits, $P$. chrysosporium (VV18) isolated from oil contaminated refinery soil of Vadodara, actinomycete Streptomyces globisporous (C3) isolated from degraded mustard strover, and Lactobacillus sp. isolated from sauerkraut. Photosynthetic bacterial inoculum was enriched from a water sample collected from a pond. All the isolates except photosynthetic bacterial inoculum were characterized using polyphasic approaches. P. chrysosporium VV18 culture was maintained on potato dextrose agar at $\mathrm{pH}$ 6.5. Streptomyces globisporous C3 was maintained on agar slant containing $(\mathrm{g} / \mathrm{L})$ glucose 4.0 , yeast extract 4.0, malt extract 10.0, and agar 20.0 at $\mathrm{pH}$ 6.5. Yeast $C$. tropicalis Y6 was maintained on MGYP agar slant containing (g/L) malt extract 3.0, glucose 10.0, yeast extract 3.0, peptone 5.0, and agar 20.0 at $\mathrm{pH} 7.0$. Lactobacillus sp. was maintained on lactic agar media ( $\mathrm{pH}$ 6.0). Photosynthetic bacterial inoculum was maintained in basal medium containing $(\mathrm{g} / \mathrm{L}) \mathrm{KH}_{2} \mathrm{PO}_{4} 0.33$, $\mathrm{MgSO}_{4} .7 \mathrm{H}_{2} \mathrm{O} 0.33, \mathrm{NaCl} 0.33, \mathrm{NH}_{4} \mathrm{Cl} 0.50, \mathrm{CaCl}_{2} .2 \mathrm{H}_{2} \mathrm{O}$ 0.05 , sodium succinate 1.0 , yeast extract 0.02 , and (0.02\%) $\mathrm{FeSO}_{4} .7 \mathrm{H}_{2} \mathrm{O} 0.01 \mathrm{mg}, \mathrm{pH} 6.8$, in natural light. All the cultures were grown at $30{ }^{\circ} \mathrm{C}$ and stored at $4{ }^{\circ} \mathrm{C}$ for further use. 
All selected microorganisms were raised separately for 10 days at $30{ }^{\circ} \mathrm{C}$ in their respective broth. After growth, all the cultures were mixed together in equal quantities to make a consortium for inoculation in paddy straw.

\section{Composting}

Paddy straw obtained after harvest of rice (40 kg/pit) was filled in aboveground perforated cemented pits $\left(1 \mathrm{~m}^{3}\right.$ dimensions) to make a composting pile. Nitrogen amendment was provided in the form of poultry dropping $(5 \mathrm{~kg} /$ pit) in the ratio of $8: 1$ to bring down the $\mathrm{C}: \mathrm{N}$ ratio $(60: 1)$ of composted mixture. Rock phosphate obtained from Rajasthan, India, was incorporated at $1 \% \mathrm{w} / \mathrm{w}$ in the pile as a source of insoluble phosphorus. The experiment was carried out at the Division of Microbiology, IARI, New Delhi, India, during the summer months of June-Aug 2012. The inoculum was added at $1 \% \mathrm{v} / \mathrm{w}$ in each treatment. All the treatments were in triplicates and one uninoculated control was also maintained. The composting mixture was mixed and water was sprinkled at regular intervals to maintain $60 \%$ moisture level throughout composting. The composting piles were turned fortnightly to maintain aeration. The temperature was recorded on daily basis at five random sites of the compost pits to monitor the progress of composting.

\section{Treatments}

T1: Paddy straw alone

T2: Paddy straw + poultry dropping

T3: Paddy straw + poultry dropping + CI

T4: Paddy straw + poultry dropping $+\mathrm{EM}$

T5: Paddy straw + poultry dropping + CI + EM (1:1 ratio)

Study of the degradation process

Samples were collected from different depths and places of pile and pooled together for enzyme assays and analysis of physical parameters at monthly intervals. The samples were preserved at $4{ }^{\circ} \mathrm{C}$ for analysis of microbial activity parameters.

\section{Enzyme assay}

The activities of different enzymes in the compost samples were analyzed at monthly intervals. The extract of compost in the citrate buffer $(0.05 \mathrm{M}, \mathrm{pH} 4.8)$ was used to assay the extracellular enzymes. The assay of various enzyme activities was based on the release of products and its quantitative determination in a reaction mixture. The extracellular hydrolytic enzymes', i.e., $\beta-1,4$ endoglucanase (carboxymethyl cellulase or CMCase; EC: 3.2.1.4) and $\beta$-1,4-exoglucanase (FPase or Filter paper lyase; EC: 3.2.1.91), activity was estimated by method of Ghose (1987) using $2 \%$ carboxymethyl cellulose and filter paper as a substrate, respectively, and represented as IU/g. One IU of enzyme represents $1 \mu \mathrm{M}$ of glucose liberated per minute of reaction. Xylanase (EC: 3.2.1.8) activity was estimated by the method of Ghose and Bisaria (1987) using $1 \%$ birch wood xylan. One IU of xylanase represents $1 \mu \mathrm{M}$ of xylose liberated per minute of reaction.

The microbial activity of compost was estimated in terms of dehydrogenase, acid/alkaline phosphatase, and fluorescein diacetate (FDA; EC: 3.1.1.3) hydrolase. Dehydrogenase (EC: 1.1.1.1) activity was estimated by the method of Casida et al. (1964) using triphenyl tetrazolium chloride as substrate. The activity of dehydrogenase is expressed as $\mu \mathrm{g}$ of TPF released per gram of compost per day. Acid phosphatase (EC: 3.1.3.2) and alkaline phosphates (EC: 3.1.3.1) were estimated by the method of Tabatabai and Bremner (1969) using $p$-nitrophenyl as substrate and expressed in $\mu \mathrm{g}$ of $p$ NP released per gram of compost per hour. Fluorescein diacetate (FDA) hydrolysis was estimated by the method of Swisher and Carroll (1980) using FDA as a substrate and expressed as $\mu \mathrm{g}$ of fluorescein released per gram of compost per hour. Total phenol concentration was analyzed in the aqueous extract of compost according to the method of Bray and Thorpe (1954) and expressed in $\mathrm{mg} / \mathrm{g}$ of dry compost.

Physiochemical parameters

Dried samples of compost were grounded and used for the estimation of physiochemical parameters (organic carbon, $\mathrm{pH}, \mathrm{EC}$, humus). Organic matter was estimated by the dry combustion method in a muffle furnace at $550{ }^{\circ} \mathrm{C}$ for $5 \mathrm{~h}$. Carbon content was estimated by the method of Navarro et al. (1993). Total N content was analyzed by Kjeldahl's method after digesting the sample with a digestion mixture (sodium sulfate and $\mathrm{CuSO}_{4}$ ) and concentrated $\mathrm{H}_{2} \mathrm{SO}_{4}$ (Jackson 1967). An extensive set of parameters was studied for checking the maturity and stability of compost, e.g., water-soluble carbon (WSC) and alkali-soluble carbon (ASC) were estimated by wet digestion method using aqueous and alkali extract $(1 \mathrm{~N} \mathrm{NaOH})$ of compost and titrating it with $0.5 \mathrm{~N}$ ferrous ammonium sulfate by the method of Walkley and Black (1934). UV-vis measurements of compost extract in distilled water and alkali $(10 \% \mathrm{w} / \mathrm{v})$ were used to calculate the E4/E6 ratio (absorbance at $465 \mathrm{~nm}$ over absorbance at $665 \mathrm{~nm}$ ) and the E2/E3 ratio (absorbance at $250 \mathrm{~nm}$ over absorbance at $365 \mathrm{~nm}$ ) as per standard protocols (Chen et al. 1977; 
Hautala et al. 2000; Thomsen et al. 2002). Electrical conductivity (EC) and $\mathrm{pH}$ measurement were performed in compost:water suspension $(1: 5 \mathrm{w} / \mathrm{v})$ by electrometric determination using handheld digital $\mathrm{EC}$ and $\mathrm{pH}$ meters (Eutech instruments, Singapore), respectively. The humus content was estimated by the method of Kononova (1966) using pyrophosphate reagent as extractant. The mature compost was analyzed for pathogen and nitrate content. Coliform and Salmonella sp. were enumerated by dilution plating method using the XLD/SS agar (Hi Media, India). Nitrate nitrogen was estimated by the method of Anderson and Ingram (1989).

\section{Statistical analysis}

The data of the various parameters of compost maturity and enzyme activities were analyzed in triplicate and subjected to ANOVA (analysis of variance) in accordance with the experimental design (completely randomized block design) using SPSS-16 statistical package to quantify and evaluate the source of variation and CD (critical difference). Correlation values were calculated at $P$ level of 0.05 standard deviation (SD). Alphabetical superscripts in table denote ranking in descending value according to Duncan's multiple range test. The treatments denoted by different letters in each column of the tables and in figures represent significantly different values among the treatments.

\section{Results and discussion}

The C:N ratio of crop residue is a determining factor for its degradation and maturity. A low $\mathrm{C}: \mathrm{N}$ ratio during the initial decomposition phase causes manifold increase in the decomposition rate (Eiland et al. 2001; Golueke 1992). Paddy straw, which was used as substrate, has a high C:N ratio of about 90:1 (Supplementary Table 1); therefore to narrow down the C:N ratio to 60:1, paddy straw was amended with poultry droppings. Extracellular enzymes are known to be involved in the depolymerization of different substrates. Some important enzymes involved in the composting process include cellulases and xylanase related to $\mathrm{C}$ mineralization, proteases and urease involved in $\mathrm{N}$ cycle, and phosphatases and arylsulfatases related to $\mathrm{P}$ and S cycles (Mondini et al. 2004). Decrease in enzymatic activity during the composting process is related to the decline in microbial activity due to reduction in the amount of available substrates (Garcia et al. 1993; Benitez et al. 1999) and indicates the maturity of the compost. Other physiochemical parameters like water-soluble carbon (WSC), organic carbon (\%), E4/E6 ratio, E2/E3 ratio, C:N ratio, $\mathrm{EC}, \mathrm{pH}$, etc. reflect on the stability and maturity of the compost. The E4/E6 ratio is used as a humification index, and the E2/E3 ratio is related to the molecular size and degree of aromaticity of the organic matter (SorianoDisla et al. 2010).

Changes in physiochemical and biochemical parameters during composting

Compost maturity and stability are the important aspects of compost quality. They are related to the degree to which the organic matter has been stabilized during the composting process. During the process of composting, organic carbon (OC) content decreased significantly from its initial value of 60 to $35-45 \%$ (Table 1) in different treatments, while the lowest value $32 \%$ was observed in the treatment inoculated with both EM and CI during the second month. In the treatment inoculated with EM, carbon content was reduced to 34.60 in 60 days. Decrease in organic carbon reflects the degradation of organic matter and its rapid maturity. During composting, in all the treatments tested, nitrogen content increased over time with values ranging from 1.13 to $2.07 \%$. Significant increase in nitrogen content was observed with EM inoculation $(1.96 \%)$. Our results are in accordance with Lee et al. (2002), who reported an increase in total nitrogen concentration during the progression of composting where the loss of volatile solids (organic matter) exceeds the loss of $\mathrm{NH}_{3}$. With the progression of paddy straw decomposition, organic carbon content decreased due to loss of carbon in the form of $\mathrm{CO}_{2}$, and nitrogen content increased due to concentration effect which resulted in decreased $\mathrm{C}: \mathrm{N}$ ratio. The initial $\mathrm{C}: \mathrm{N}$ ratio was 90:1, which dropped down to 17.83 with EM inoculation within 60 days, which validated the role of EM in the degradation of organic matter in hastening the composting process. Lowest $\mathrm{C}: \mathrm{N}$ ratio (16:1) was observed in the treatment inoculated with EM and CI.

Humus content of all the treatments increased with time, which indicated the correct progression of composting. The highest humus content $(4.82 \%)$ was observed in T5 treatment amended with EM and CI within 60 days. A similar significant increase in humus $(4.54 \%)$ was observed in treatment T4, which was amended with EM, indicating compost stability within 60 days of the composting period.

Electric conductivity (EC) reflects the degree of salinity in the composting end product, which reflects phytotoxic/ phyto-inhibitory effects (e.g., low germination rate, withering) on the growth of plants (Lin 2008). In EM-inoculated sample, after 60 days of composting, EC was recorded to be $2.56 \mathrm{mS} / \mathrm{cm}$ which also showed its stability like other treatments. During the process of composting, the volatilization of ammonia and the precipitation of mineral salts could be the possible reasons for the decrease in EC at the later phase of composting (Wong et al. 1995). 


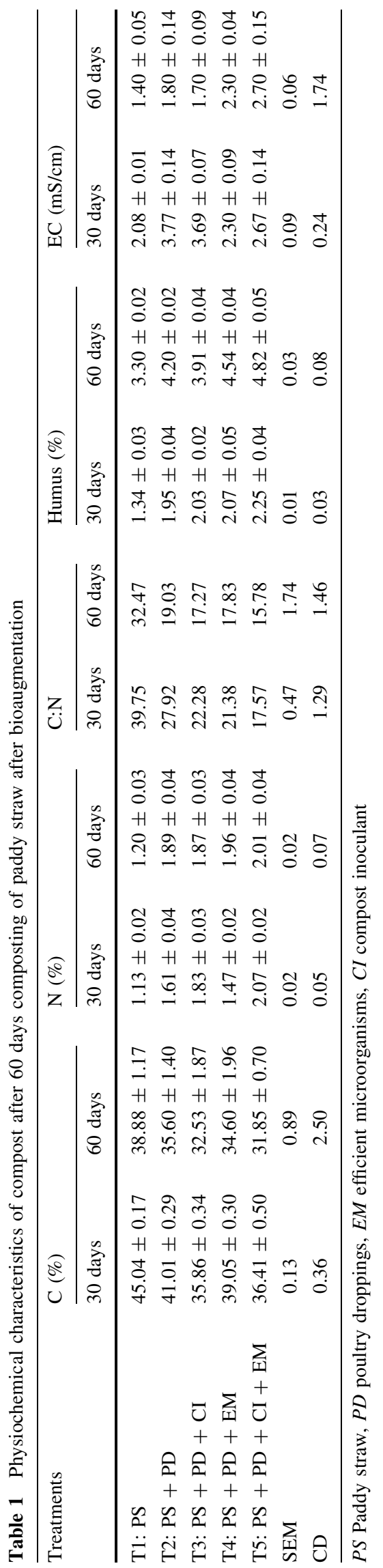

Generally EC value $<4 \mathrm{mS} / \mathrm{cm}$ is desirable for mature compost. The temperature at different time intervals was recorded during the composting process. In all the treatments, the temperature increased during the composting process in the initial 10 days to $50{ }^{\circ} \mathrm{C}$, while atmospheric temperature was $21^{\circ} \mathrm{C}$. Finally, it declined to ambient level after 30 days and remained stable till 60 days (Supplementary Figure 1).

Water soluble carbon (WSC) is the soluble form of carbon which is most easily accessible and biodegradable during composting. It contains sugars, amino acids, and phenols (Garcia et al. 1992). In our study, WSC was observed to be $0.20 \%$ (Table 2) in the treatment with EM supplementation, indicating its maturity which is supported by Bernal et al. (1998) and Hue and Liu (1995) who have recommended WSC $>1.7$ and $>1 \%$, respectively, at the time of maturity. The presence of phenol was recorded in all the treatments $(1.72-4.24 \mathrm{mg} / \mathrm{g})$ and this showed that the lignin component of paddy straw was degraded by the action of phenol oxidase and lignin peroxidase of resident and inoculated microorganisms. However, low values of phenol of 2.73 and $1.72 \mathrm{mg} / \mathrm{g}$ (Table 2) were observed in EM and EM with CI-inoculated treatments, respectively. Phenolic compounds' degrading capability of some strains of fungus in EM and CI consortium may be the reason for the reduction of phenol in the inoculated treatments. With the inoculation of EM, WSC:total $\mathrm{N}$ ratio was observed to be 0.10 (Table 2) at 60 days, reconfirming compost maturity. Hue and Liu (1995) proposed WSC:total N ratio $<0.70$ to judge the maturity of compost. However, Bernal et al. (1998) proposed the WSC:total $\mathrm{N}$ ratio $<0.55$ for mature and stabilized compost.

In the present study, the E4/E6 ratio increased from 4.29 to 7.71 with $\mathrm{EM}$ inoculation, and E2/E3 was 3.38 within 60 days of paddy straw composting. The E4/E6 ratio is used as a humification index which reflects the maturity of the compost (Zbytniewski and Buszewski 2005), and E2/ E3 ratio is related to the molecular size and degree of aromaticity of the organic matter (Peuravuori and Pihlaja 1997). The mature compost samples were analyzed for coliforms and Salmonella sp. which were found to be absent in all the samples. The nitrate content in compost was analyzed at the time of maturity and found to be in the range of $440-640 \mu \mathrm{g} / \mathrm{g}$ of dry compost which confirms the nitrate en-routing during composting.

Assay of cellulolytic enzyme

In the process of composting, the production of extracellular hydrolytic enzymes by microbes plays an important role in starting stage of degradation. These hydrolytic enzymes degrade the lignocellulosic substrate to simple monomers. Carboxymethyl cellulase (CMCase) activity 
Table 2 Maturity parameters of paddy straw compost after 60 days of composting

\begin{tabular}{|c|c|c|c|c|c|c|}
\hline Treatments & $\begin{array}{l}\text { Water-soluble } \\
\text { carbon (WSC) }(\%)\end{array}$ & $\begin{array}{l}\text { Alkali-soluble } \\
\text { carbon }(\%)\end{array}$ & $\begin{array}{l}\text { Total phenol } \\
(\mathrm{mg} / \mathrm{g})\end{array}$ & E4/E6 & E2/E3 & $\begin{array}{l}\text { WSC:total } \\
\mathrm{N}\end{array}$ \\
\hline T1: PS & $1.22 \pm 0.10^{\mathrm{a}}$ & $6.18 \pm 0.43^{b}$ & $2.39 \pm 0.016^{\mathrm{b}}$ & $5.24 \pm 0.05^{\mathrm{e}}$ & $3.29 \pm 0.04^{\mathrm{bc}}$ & 1.02 \\
\hline $\mathrm{T} 2: \mathrm{PS}+\mathrm{PD}$ & $0.81 \pm 0.08^{\mathrm{b}}$ & $12.36 \pm 0.54^{\mathrm{a}}$ & $4.24 \pm 1.10^{\mathrm{a}}$ & $6.17 \pm 0.05^{\mathrm{d}}$ & $3.25 \pm 0.04^{\mathrm{c}}$ & 0.43 \\
\hline T3: PS + PD + CI & $0.22 \pm 0.03^{\mathrm{c}}$ & $6.02 \pm 0.08^{\mathrm{b}}$ & $4.03 \pm 0.11^{\mathrm{a}}$ & $8.17 \pm 0.10^{\mathrm{a}}$ & $3.23 \pm 0.02^{\mathrm{c}}$ & 0.12 \\
\hline $\mathrm{T} 4: \mathrm{PS}+\mathrm{PD}+\mathrm{EM}$ & $0.20 \pm 0.02^{\mathrm{c}}$ & $6.15 \pm 0.08^{\mathrm{b}}$ & $2.73 \pm 0.36^{\mathrm{b}}$ & $7.71 \pm 0.08^{\mathrm{b}}$ & $3.38 \pm 0.05^{\mathrm{ab}}$ & 0.10 \\
\hline $\mathrm{T} 5: \mathrm{PS}+\mathrm{PD}+\mathrm{CI}+\mathrm{EM}$ & $0.23 \pm 0.05^{\mathrm{b}}$ & $6.48 \pm 0.09^{\mathrm{b}}$ & $1.72 \pm 0.12^{\mathrm{c}}$ & $6.53 \pm 0.04^{\mathrm{c}}$ & $3.42 \pm 0.03^{\mathrm{a}}$ & 0.11 \\
\hline SEM & 0.03 & 0.23 & 0.13 & 0.05 & 0.03 & \\
\hline $\mathrm{CD}$ & 0.09 & 0.64 & 0.36 & 0.13 & 0.07 & \\
\hline
\end{tabular}

All the superscript letters denote ranking in descending order, based on Duncan's Multiple Range Test, means with the same letter are not significantly different

$P S$ Paddy straw, $P D$ poultry droppings, $E M$ efficient microorganisms, $C I$ compost inoculant

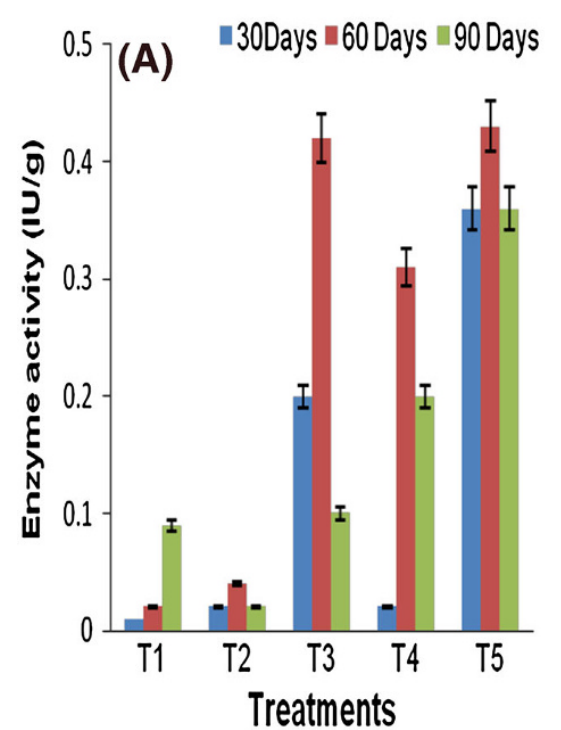

Fig. 1 Cellulolytic enzyme activity at various time intervals during composting of paddy straw. a CMCase, b FPase, c xylanase. TI Paddy straw alone, $T 2$ paddy straw + poultry dropping, $T 3$ paddy

was higher at 60 days of composting and then declined in all the treatments (Fig. 1a) at 90 days. $\beta-1,4$ exoglucanase (FPase) enzyme activity increased (Fig. 1b) during the later phase (90 days) of composting in all the treatments. Few studies had also reported a high activity of cellulolytic enzyme during the active phase of composting (Gaind et al. 2008; Pandey et al. 2009). The highest value of CMCase $(0.43 \mathrm{IU} / \mathrm{g})$ was observed at 60 days, whereas the highest activity of FPase $(0.47 \mathrm{IU} / \mathrm{g})$ was observed at 90 days in the treatment supplemented with CI and EM. $\beta-1,4$ Endoglucanase (CMCase) acts upon the native cellulose which provide reactive sites for the action of exoglucanase (FPase); so this could be a possible reason for the high activity of CMCase at 60 days and FPase at 90 days of composting. The activity of xylanase enzyme was highest in the initial stage of composting; then, a decline (Fig. 1c)

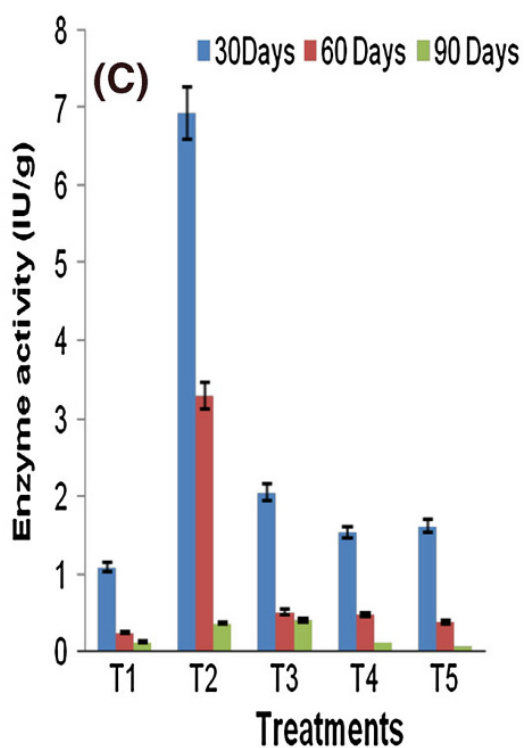

straw + poultry dropping + CI, T4 paddy straw + poultry dropping + EM, T5 paddy straw + poultry dropping $+\mathrm{CI}+\mathrm{EM}$

was observed in all the treatments at a later stage of composting. Pandey et al. (2009) also observed the same pattern of high activity of xylanase in the initial stages of composting.

\section{Estimation of microbial activity}

Dehydrogenase activity gives information about microbial activity and maturity of compost (Barrena et al. 2008). The highest dehydrogenase activity (158.64 $\mu \mathrm{g} \mathrm{TPF} / \mathrm{g} /$ day) was observed at 60 days (Fig. 2a) in treatment amended with $\mathrm{CI}$ and EM then declined as the composting proceeded. This showed high microbial colonization and active decomposition of substrate in the first 2 months of the composting process. The decrease in dehydrogenase activity toward 90 days indicates the absence of active 

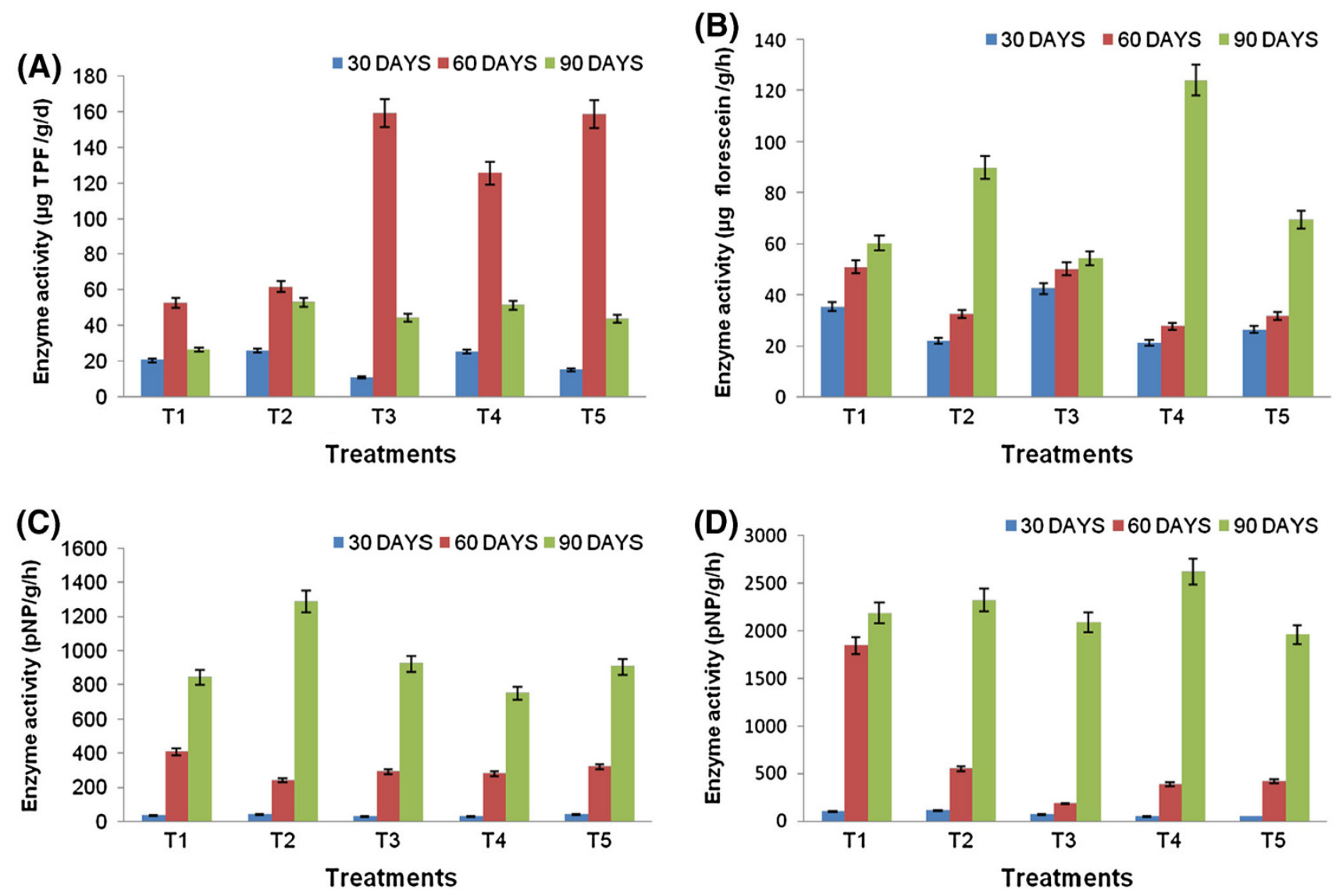

Fig. 2 Microbial enzyme activity at various time intervals during composting of paddy straw. a Dehydrogenase, b FDA hydrolase, c acid phosphatase, $\mathbf{d}$ alkaline phosphatase. $T 1$ Paddy straw alone, $T 2$

paddy straw + poultry dropping, T3 paddy straw + poultry dropping + CI, T4 paddy straw + poultry dropping + EM, T5 paddy straw + poultry dropping $+\mathrm{CI}+\mathrm{EM}$

decomposition and confirmed that the compost was mature. Pandey et al. (2009) also observed high activity of dehydrogenase at 60 days of composting. FDA hydrolysis can also be used to measure the microbial activity in compost. The highest FDA hydrolysis $(124.17 \mu$ g fluorescein $/ \mathrm{g} / \mathrm{h}$ ) was achieved at 90 days with EM augmentation. Higher FDA hydrolysis activity was observed in all treatments with increase of composting period. A similar pattern of increasing FDA hydrolysis activity with progression of composting time was also reported by Cayuela et al. (2008) and Inbar et al. (1991).

Acid/alkaline phosphatase activity plays an important role in the mineralization of organic phosphorus and this enzyme is generally activated when $\mathrm{P}$ availability is low (Nannipieri et al. 1979). Both the enzyme activities (alkaline and acid phosphatase) increased with the duration of the composting period (Fig. 2c, d). The highest activity of alkaline phosphatase $(2,622.56 \mu \mathrm{g} \quad \mathrm{NP} / \mathrm{g} / \mathrm{h})$ was achieved with EM augmentation. A similar trend of increased alkaline phosphatase activity with progression of the composting period with bioaugmented paddy straw was

also observed by Tiquia et al. (2001) and Pandey et al. (2009).

Correlation analysis between maturity and microbial activity parameters of compost

To check the maturity of compost, various physiochemical parameters were analyzed which were correlated with microbial enzyme activities. Alkali-soluble carbon is strongly positively correlated with xylanase activity $(r=0.987, p<0.05)$ and total phenol content $(r=0.650$, $p<0.05$ ) (Table 3). This indicates that EM inoculation selectively degrades lignin rapidly and simultaneously releasing soluble carbon which is again utilized by autochthonous and amended microbes for their growth and metabolism, leading to compost maturity. Strong positive correlation $(r=0.771, p<0.05)$ was also observed between E4/E6 ratio, which is an indicator of humification index, with dehydrogenase activity. This observation also reconfirms the role of inoculated microorganism in hastening the degradation process. 


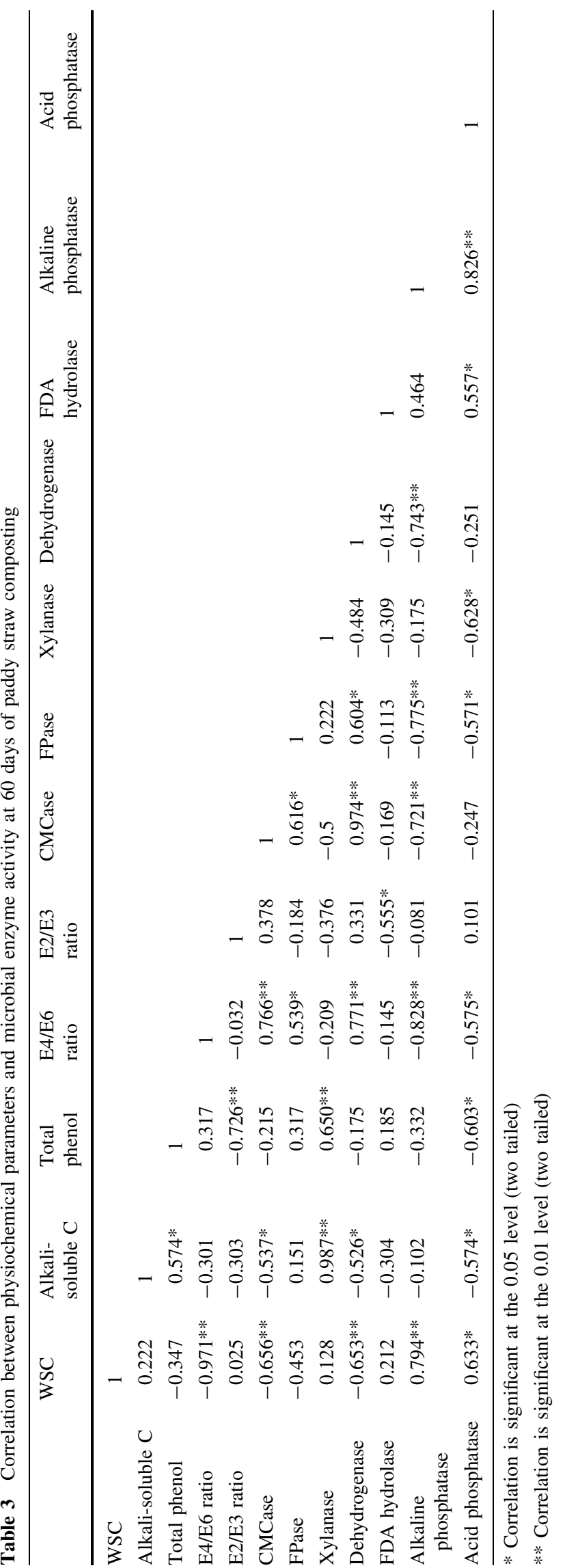

\section{Conclusions}

The result of this study indicates the importance of EM inoculation to hasten the composting process. The evaluation of various analytical parameters suggests that rapid composting process may be carried out by combined inoculation of EM and CI. This bioaugmented process may result in mature compost within 60 days of decomposition.

Conflict of interests The authors declare that they have no competing interests.

Open Access This article is distributed under the terms of the Creative Commons Attribution License which permits any use, distribution, and reproduction in any medium, provided the original author(s) and the source are credited.

\section{References}

Anderson JM, Ingram JSI (1989) Tropical soil biology and fertility: A handbook of methods. CAB International, Wallingford

Antil RS, Raj D (2012) Chemical and microbiological parameters for the characterization of maturity of composts made from farm and agro-industrial wastes. Arch Agron Soil Sci 58(8):833-845

Barrena R, Vasquez F, Sanchez A (2008) Dehydrogenase activity as a method for monitoring the composting process. Bioresour Technol 99:905-908

Benitez E, Nogales R, Elvira C, Masciandaro G, Ceccanti B (1999) Enzyme activities as indicators of the stabilization of sewage sludges composting with Eisenia foetida. Bioresour Technol 67:297-303

Bernal MP, Paredes C, Sanchez-Monedero MA, Cegarra J (1998) Maturity and stability parameters of compost prepared with a wide range of organic wastes. Bioresour Technol 63:91-99

Bray HC, Thorpe WV (1954) Analysis of phenolic compounds of interests in metabolism. Methods Biochem Anal 1:27-32

Casida LE Jr, Klein DA, Santaro T (1964) Soil dehydrogenase activity. Soil Sci 98:371-376

Cayuela ML, Mondini C, Sanchez-Monedero MA, Roig A (2008) Chemical properties and hydrolytic enzyme activities for the characterisation of two-phase olive mill wastes composting. Bioresour Technol 99(10):4255-4262

Chen Y, Senesi N, Schnitzer M (1977) Information provided on humic substances by E4/E6 ratios. Soil Sci Soc Am J 41:352-358

Daly MJ, Stewart DPC (1999) Influence of "effective microorganisms" (EM) on vegetable production and carbon mineralization-a preliminary investigation. J Sustain Agric 2(3):15-25

Devi S, Sharma CR, Singh K (2010) Microbiological biodiversity in poultry and paddy straw wastes in composting systems. Braz $\mathrm{J}$ Microbiol 3:288-296

Eiland F, Klamer M, Lind AM, Leth M, Baath E (2001) Influence of initial $\mathrm{C}: \mathrm{N}$ ratio on chemical and microbial composition during long term composting of straw. Microbial Ecol 41:272-280

Gadde B, Menke C, Wassmann R (2009) Rice straw as a renewable energy source in India, Thailand, and the Philippines: overall potential and limitations for energy contribution and greenhouse gas mitigation. Biomass Bioenerg 33(11):1532-1546

Gaind S, Nain L (2007) Chemical and biological properties of wheat soil in response to paddy straw incorporation and its biodegradation by fungal inoculants. Biodegradation 4:495-503 
Gaind S, Nain L, Patel VB (2008) Quality evaluation of cocomposted wheat straw, poultry droppings and oil seed cakes. Biodegradation 20(3):307-317

Garcia C, Hernandez T, Costa F, Ceccanti B, Ciardi C (1992) Changes in ATP content, enzyme activity and inorganic nitrogen species during composting of organic wastes. Can J Soil Sci $72: 243-253$

Garcia C, Hernandez T, Costa C, Ceccanti B, Masciandaro G, Ciardi C (1993) A study of biochemical parameters of composted and municipal wastes. Bioresour Technol 44:17-23

Ghose TK (1987) Measurements of cellulase activities. Pure Appl Chem 59:257-268

Ghose TK, Bisaria VS (1987) Measurement of hemicellulase activities part 1: xylanases. Pure Appl Chem 59:1739-1752

Golueke CG (1992) Bacteriology of composting. Biocycle 33:55-57

Hautala K, Peuravuori J, Pihlaja K (2000) Measurement of aquatic humus content by spectroscopic analysis. Water Resour Bull $34: 246-258$

Hue NV, Liu J (1995) Predicting compost stability. Compost Sci Util $3: 8-15$

Inbar Y, Boehm MJ, Hoitink HAJ (1991) Hydrolysis of fluorescein diacetate in sphagnum peat container media for predicting suppressiveness to damping off caused by Pythium ultimum. Soil Biol Biochem 23:479-483

Jackson ML (1967) Soil chemical analysis. Prentice Hall of India Ltd, New Delhi

Jiang T, Schuchardt F, Li G, Guo R, Zhao Y (2011) Effect of C:N ratio, aeration rate and moisture content on ammonia and greenhouse gases emission during the composting. J Environ Sci 23(10):754-1760

Kononova MM (1966) Soil organic matter. Pergamon Press, Oxford

Lee BI, Kim PJ, Chang WK (2002) Evaluation of stability of compost prepared with Korean food waste. Soil Sci Plant Nutr 48:1-8

Lin C (2008) A negative-pressure aeration system for composting food wastes. Bioresour Technol 99:7651-7656

Mondini C, Fornasier F, Sinicco T (2004) Enzymatic activity as a parameter for the characterization of the composting process. Soil Biol Biochem 36:1587-1594

Nannipieri P, Pedrazzini F, Arcara PG, Piovanelli C (1979) Changes in amino acids, enzyme activities, and biomasses during soil microbial growth. Soil Sci 127:26-34
Navarro AF, Cegarra J, Roig A, Garcia D (1993) Relationship between organic matter and carbon contents of organic wastes. Bioresour Technol 44:203-207

Pandey AK, Gaind S, Ali A, Nain L (2009) Effect of bioaugmentation and nitrogen supplementation on composting of paddy straw. Biodegradation 20:293-306

Peuravuori J, Pihlaja K (1997) Molecular size distribution and spectroscopic properties of aquatic humic substances. Anal Chim Acta 337:133-149

Soriano-Disla JM, Gomez I, Guerrero C, Navarro-Pedreno J, GarciaOrenes F (2010) The potential of NIR spectroscopy to predict stability parameters in sewage sludge and derived compost. Geoderma 158:93-100

Swisher R, Carroll GC (1980) Fluorescein diacetate hydrolysis as an estimator of microbial biomass on coniferous needle surfaces. Microb Ecol 6(3):217-226

Tabatabai MA, Bremner JM (1969) Use of $p$-nitrophenyl phosphate for assay of soil phosphatase activity. Soil Biol Biochem 1:301-307

Thomsen M, Lassen P, Dobel S, Hansen PE, Carlsen L, Mogensen BB (2002) Characterisation of humic materials of different origin: a multivariate approach for quantifying the latent properties of dissolved organic matter. Chemosphere 49:1327-1337

Tiquia SM, Wan JHC, Tam NFY (2001) Extracellular enzyme profile during co-composting of poultry manure and yard trimmings. Process Biochem 36:813-820

Veena SS, Pandey M (2011) Paddy straw as a substrate for the cultivation of Lingzhi or Reishi medicinal mushroom, Ganoderma lucidum (W.Curt.:Fr.) P. Karst. in India. Int J Med Mushrooms. 13(4):397-400

Walkley A, Black IA (1934) An examination of the Degtjareff method for determining organic carbon in soils: effect of variations in digestion conditions and of inorganic soil constituents. Soil Sci 63:251-263

Wong JWC, Li SWY, Wong MH (1995) Coal fly ash as a composting material for sewage sludge: effects on microbial activities. Environ Technol Lett 16:527-537

Zbytniewski R, Buszewski B (2005) Characterization of natural organic matter (NOM) derived from sewage sludge compost. Part 2: multivariate techniques in the study of compost maturation. Bioresour Technol 96(4):479-484 